\title{
Geohydraulic study of aquifer characteristics in parts of Enugu North Local Government Area of Enugu State using electrical resistivity soundings
}

\author{
Bethrand Ekwundu Oguama ${ }^{1}$. Johnson Cletus Ibuot $^{2} \cdot$ Daniel Nnaemeka Obiora $^{2}$
}

Received: 24 May 2019 / Accepted: 14 April 2020 / Published online: 23 April 2020

(C) The Author(s) 2020

\begin{abstract}
Geophysical survey employing vertical electrical sounding (VES) was achieved in Enugu State College of Education (Technical). Schlumberger electrode configuration was used in acquiring the data which were interpreted using the WinResist software. Four to five geoelectric layers were delineated from the interpreted results. The hydraulic parameters (hydraulic conductivity, porosity, formation factor, tortuosity and transmissivity) were estimated from the values of resistivity and thickness which are primary geoelectric parameters. The result shows the hydraulic conductivity varying from 2.71 to $70.45 \mathrm{~m} /$ day, transmissivity: $49.2288-1127.944 \mathrm{~m}^{2} /$ day, porosity: $33.71-49.44 \%$, formation factor: $0.0014-0.0026$ and tortuosity: $0.2667-0.2935$. The zones with high and low values of these parameters were delineated. The potentiality of the aquifer units show moderate to high a reflection of the heterogeneity of the subsurface which is affected by the composition and geometry of the formation. The result from this study provides some important conclusions for future groundwater exploration and management.
\end{abstract}

Keywords Groundwater · VES · Hydraulic conductivity · Transmissivity $\cdot$ Porosity

\section{Introduction}

The subsurface characteristics are controlled by soil composition, dissolved ions, thickness and water contents. The increase in population and urbanisation has put a lot of pressure on subsurface structures as well as groundwater repositories. Potable water is a necessity and plays a major role in determining the growth and development of a settlement. Enugu has witnessed an increased in population which has signal an increase in local economy, the inhabitants being farmers, civil servants, students, business men and women. They rely mostly on boreholes as a major renewable freshwater source, thus increasing the demand for potable water supply. In subsurface formations such as sedimentary or crystalline rocks, groundwater exists within

Johnson Cletus Ibuot

johnson.ibuot@unn.edu.ng

1 Department of Physics Education, Enugu State College of Education (Technical), Enugu, Nigeria

2 Department of Physics and Astronomy, University of Nigeria, Nsukka, Nigeria the saturated layers of sand, gravel and pore spaces (Agbasi and Etuk 2016). In order to pursue large-scale development of groundwater, it is essential to have a reliable knowledge about groundwater potential and geohydraulic parameters (Singh 1985, 2005; Ibuot et al. 2013, 2019; George et al. 2018). Groundwater yield is affected by the physical and hydrogeologic properties of the aquifer layers. The variation of pore spaces and their connectivity across the subsurface characterises a geologic/hydrogeologic units and greatly influences the movement of groundwater. The porosity and interconnectivity of rocks can change depending on the compaction and cementation factors (George et al. 2017). The deeper parts of an active aquifer (unconfined aquifer) are more saturated due to the gravity which causes the water to flow downward, and the upper level of the saturated layer being the water table.

The quality of groundwater is greatly affected by the amount of contaminants that percolate into the aquifer units through the overlying layers (Obiora et al. 2015; Ibuot et al. 2017). The movement of groundwater pollutants is controlled by the geohydraulic characteristics of the subsurface, which greatly affects the flow dynamics of the aquifer units. Also, the distribution of groundwater elevation in the 
saturated zone determines the direction in which the water will flow.

Environment can be evaluated without interfering with the hydrogeologic system through the use of geophysical studies (Yahaya et al. 2009). The results of these geophysical studies will help in solving the problems of fail boreholes as a result of wildcat drilling, since it will give useful information for characterising the heterogeneity of the subsurface lithology and delineate the aquiferous units. Electrical resistivity method utilising VES has proved to be useful in groundwater study (George et al. 2014; Ibuot et al. 2013; Niwas and Singhal 1981; Soupious et al. 2007) and has been widely used in determining the depth to water table, aquifer geometry and groundwater quality by analysing measured apparent resistivity field data. The applications of indirect and non-invasive geophysical measurement have the potential to predict the distributions of the aquifer geohydraulic parameters more effectively. This study is aimed at stratifying the subsurface and also at determining the distribution of the hydraulic parameters in aquifer repositories through the use of electrical resistivity data.

\section{Location and the geology of the study area}

The study area located within the state capital and lies between latitudes $6^{\circ} 25^{\prime} 0^{\prime \prime} \mathrm{N}$ and $6^{\circ} 29^{\prime} 0^{\prime \prime} \mathrm{N}$, and longitudes $7^{\circ} 28^{\prime} 0^{\prime \prime}$ and $7^{\circ} 32^{\prime} 0^{\prime \prime}$ (Fig. 1a, b) in Enugu State and geologically located within the Anambra sedimentary basin in the Eastern part of Nigeria. The two climatic seasons that influence the study area are the dry and wet seasons; the dry season starts from November to March, while the wet season starts from April to October. Also found in the study area are the residual hills and dry valleys, which are related to the rock type or geologic formation underlying the area (Stow 2005). The escarpment of Enugu is formed by the Ajali sandstone and the sandstone units of the Mamu Formation (Egesi 2017). Underlying the study area is the Enugu shale with outcrop of Mamu Formation in some areas and is composed of shale and sandstone. The formation is said to be coaliferous and is also fractured; the fractured nature makes it a potential aquifer repository. According to Uzoije et al. (2014), the Ajali aquifer is trapped by the shaley impermeable base of the Mamu formation and the aquifer thickness varies from one location to another separated by thin bands of impermeable clay and shaley sands.

\section{Data acquisition and analysis}

Data from seven vertical electrical sounding (VES) points were acquired on the study area using the IGIS resistivity meter employing the Schlumberger electrode array with the half current electrode spacing $\left(\frac{A B}{2}\right)$ varying between 1.0 and $500 \mathrm{~m}$ and half potential electrode spacing $\left(\frac{M N}{2}\right)$ varying between 0.25 and $20 \mathrm{~m}$. The direction of electrodes spread was chosen to enable a more or less horizontal electrode line in order to avoid topographic effects. Using Eq. (1), the apparent resistivity $\left(\rho_{\mathrm{a}}\right)$ was determined.

$\rho_{\mathrm{a}}=\pi \cdot\left[\frac{\left(\frac{A B}{2}\right)^{2}-\left(\frac{M N}{2}\right)^{2}}{M N}\right] \cdot R_{\mathrm{a}}$

where $A B$ is the distance between the two current electrodes, $M N$ is the distance between the potential electrodes and $R_{\mathrm{a}}$ is the apparent electrical resistance measured from the equipment. The equation can be simplified to

$\rho_{\mathrm{a}}=K \cdot R_{\mathrm{a}}$

where $K$ is the geometric factor: $\pi \cdot\left[\frac{\left(\frac{A B}{2}\right)^{2}-\left(\frac{M N}{2}\right)^{2}}{M N}\right]$.

The Global Positioning System (GPS) was used in measuring the coordinates of the sounding points. In processing the data, apparent resistivity obtained was plotted against $\frac{A B}{2}$ using a bi-logarithm graph and the curves were smoothened and quantitatively interpreted in terms of true resistivity and thickness by a conventional manual curves and auxiliary charts (Orellana and Mooney 1966). The manually interpreted data were improved upon using the WinResist software package to perform automated approximation of the initial resistivity model from the observed data using inversion technique, and the modelled geological curves were obtained (Figs. 2, 3). The interpretation of the resistivity curves was based on the number of layers depicted on the observed curves and models that are geologically reasonable and produce acceptable fit. The geoelectric parameters of different layers are obtained after a number of iterations with minimal RMS error.

To avoid drilling abortive wells, geophysical investigation is imperative because it helps to delineate aquifer (or potential water bearing geological units), while on the other hand, the assessment of the aquifer repositories traditionally determined from parameters obtained from well pump tests and well log data (Singh 2005), which is timeconsuming and expensive. A faster and less cost-effective means of determining these parameters involves the estimation of some geohydraulic parameters (hydraulic conductivity, transmissivity, porosity, tortuosity and formation factor) from primary electrical resistivity data (resistivity and thickness) particularly where bore wells are not sufficient or not available (Kelly 1977; Niwas and Singhal 1981; Singh 2005; Dhakate and Singh 2005; George et al. 2015; Ibuot et al. 2019). 


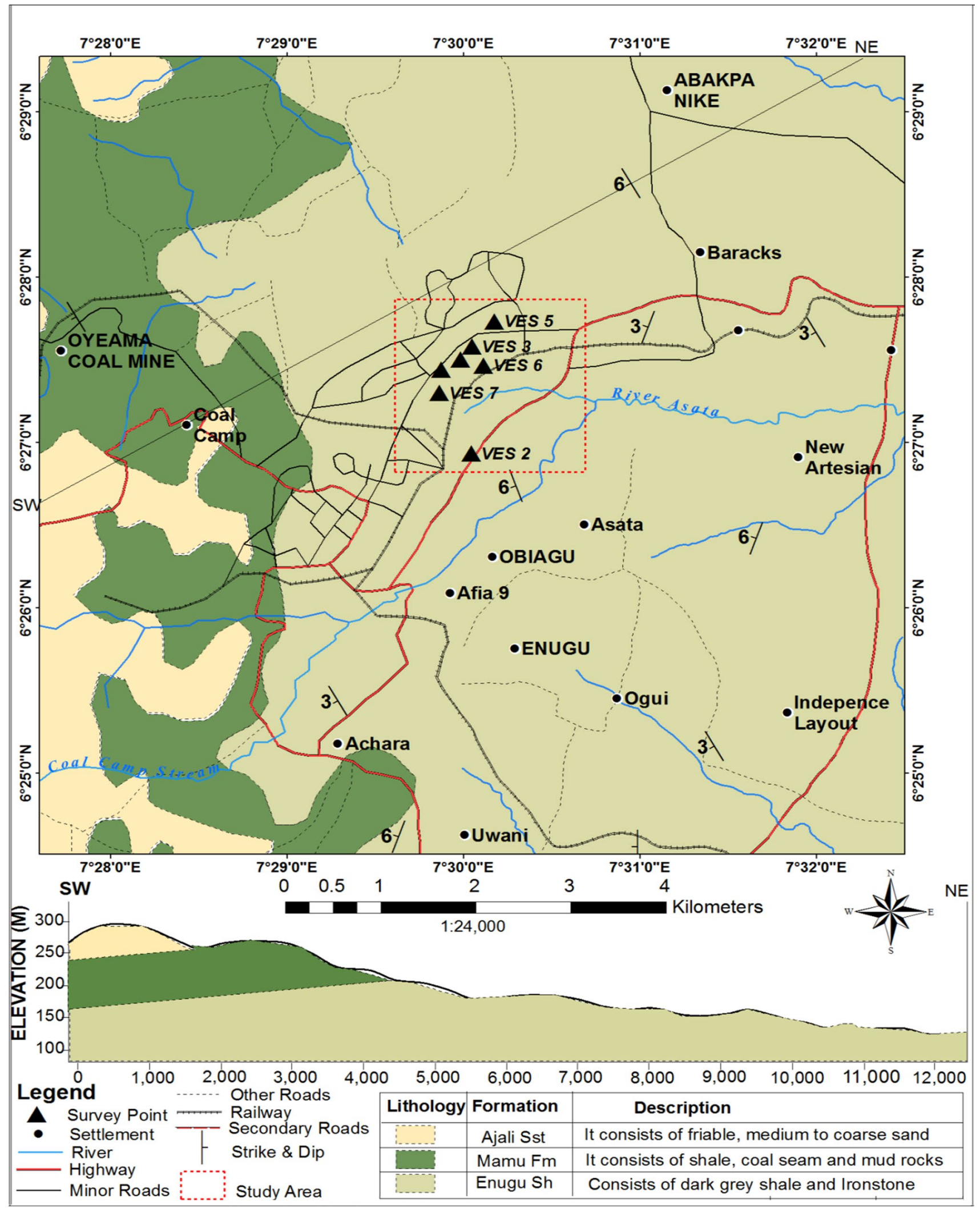

Fig. 1 Geologic map and geologic cross section of Enugu showing the VES points 


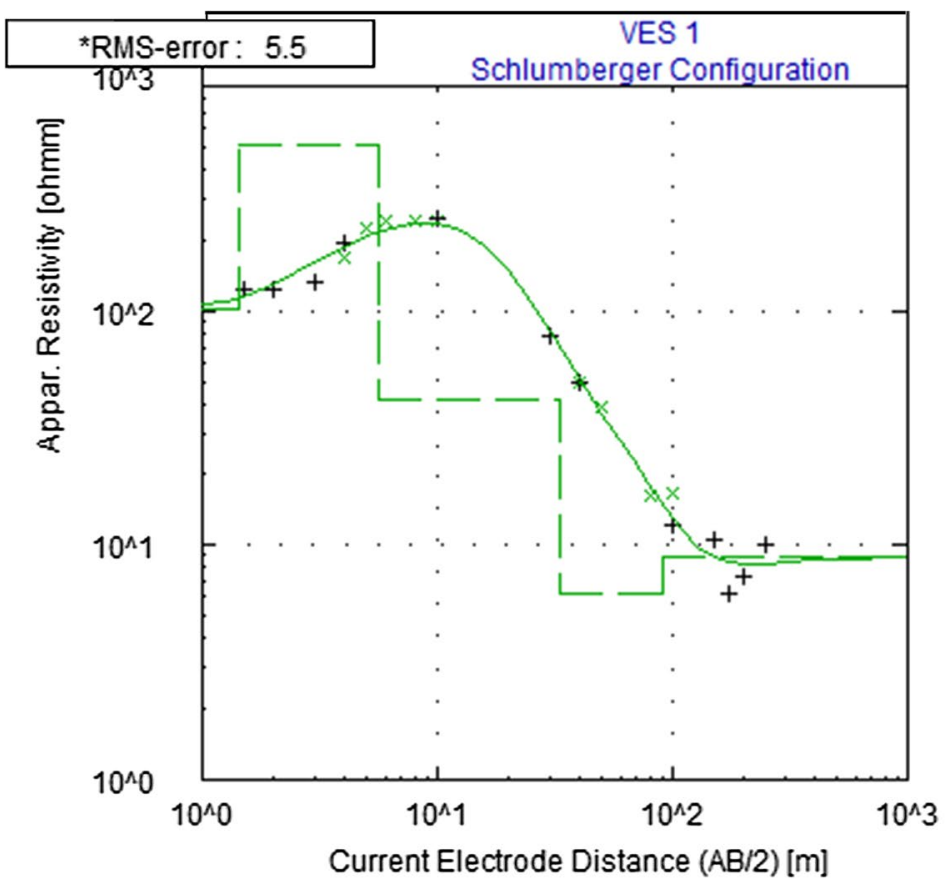

\begin{tabular}{|llll|}
\hline No & Res & Thick & Depth \\
\hline 1 & 101.2 & 1.4 & 1.4 \\
2 & 515.4 & 4.1 & 5.6 \\
3 & 42.3 & 27.8 & 33.4 \\
4 & 6.2 & 56.4 & 89.8 \\
5 & 8.9 & -- & -- \\
* & \\
RMS on smoothed data
\end{tabular}

Fig. 2 A modelled VES curve at VES 1

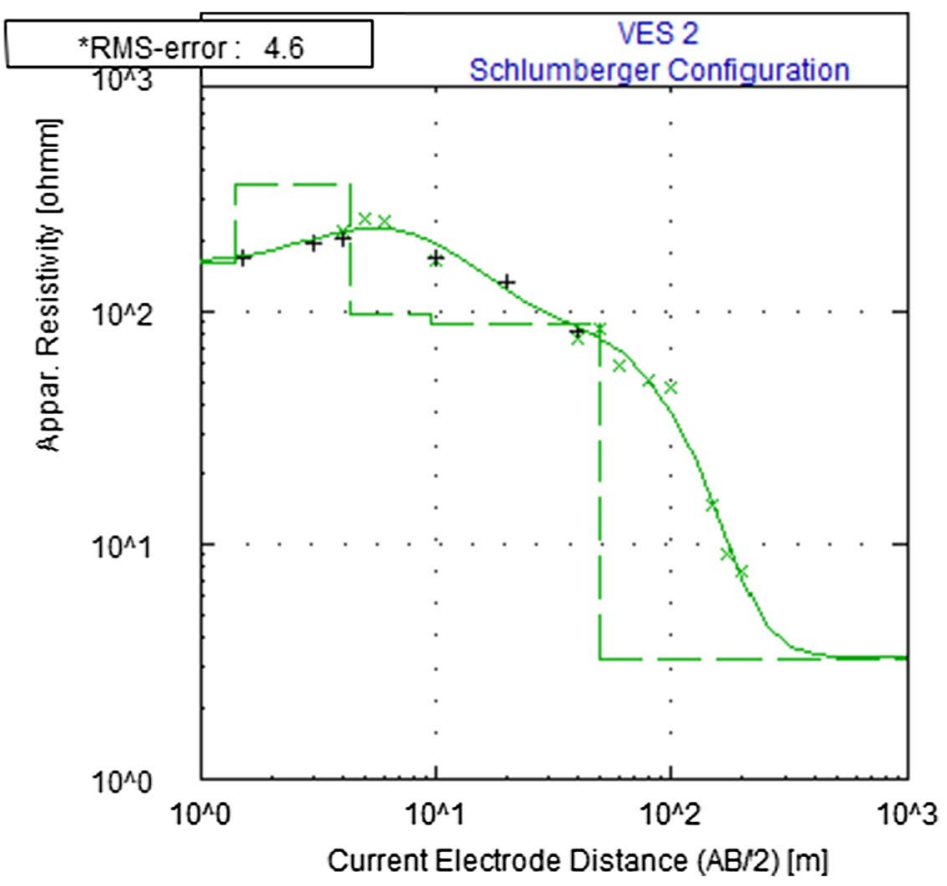

\begin{tabular}{|lccc|}
\hline No & Res & Thick & Depth \\
\hline 1 & 161.2 & 1.4 & 1.4 \\
2 & 346.5 & 2.9 & 4.3 \\
3 & 98.0 & 5.2 & 9.5 \\
4 & 88.3 & 40.4 & 49.9 \\
5 & 3.3 &.-- &.-- \\
& & & \\
* & \\
\end{tabular}

Fig. 3 A modelled VES curve at VES 2

According to Heigold et al. (1979), hydraulic conductivity $(K)$ is related to the bulk resistivity of the aquifer through Eq. (3). This parameter characterises the dynamic behaviour of hydrogeologic unit which allows flow of groundwater and also affects the yield of wells and contaminant spread.
$K=386.40 R_{r w}^{-.93283}$

where $R_{r w}$ is the aquifer bulk resistivity which can also be express as $\rho_{\mathrm{a}}$ in $\Omega \mathrm{m}$. 
And in accordance with Niwas and Singhal (1981), the analytical relationship between aquifer transmissivity $(T)$, hydraulic conductivity $(K)$ and aquifer thickness $(h)$ is given by Eq. (4);

$T=K h$

The hydraulic conductivities were multiplied with the aquifer thickness of interpreted VES stations to determine aquifer transmissivity.

Porosity which describes the volume of pore space in rocks in relation to the total rock volume was estimated using Eq. (5) (Marotz 1968). Its values vary across the subsurface and are affected by grain size distribution and the geometry of the pore space

$\phi=25.5+4.5 \ln K$

where $K$ is hydraulic conductivity and $\phi$ is the porosity.

According to Archie (1942), the formation factor $(F)$ which represents the microscopic property of the subsurface materials can be determined using Eq. (6). This parameter combines some properties such as porosity, pore shape and diagenetic cementation which influence electrical current flow

$F=a \phi^{-m}$

where $\phi$ is the porosity, $\mathrm{m}$ is the cementation factor and $a$ is the geometry factor. If electric current flow follows the path of fluid flow through pore space, then the relationship between the formation factor $(F)$ and tortuosity $(\tau)$ is given by Eq. (7). This parameter also depends on other factors such as shape of the channels connecting the pores

$\tau=(F \phi)^{1 / 2}$

where $\phi$ is porosity.

\section{Result and discussion}

The interpretation gives the values of resistivity, thickness and depth for each of the electro-stratigraphy layers within the maximum current electrode separation (Table 1). The study area is characterised by heterogeneous lithology with four to five geoelectric layers with resistivity values varying from low to high values. The primary aquifer parameters (resistivity and thickness) are determined from Table 1 and used to estimate the geohydraulic parameters (Table 2). The aquifer layer has resistivity and thickness ranging from 6.2 to $204.2 \Omega \mathrm{m}$ and $18.2-56.4 \mathrm{~m}$, respectively. The lithology of this layer can be said to compose of sand intercalated with clay and shale. It can be inferred from the result that this layer is less conductive. Figure 4a shows a geoelectric section showing the variation of resistivities with depths; the numbers within the profile indicate the values of resistivity in $\Omega \mathrm{m}$ at various depths. The spatial distribution of

Table 1 Results of geoelectric survey of the study area

\begin{tabular}{|c|c|c|c|c|c|c|c|c|c|c|c|c|c|c|c|c|}
\hline \multirow[t]{2}{*}{ VES stations } & \multirow[t]{2}{*}{ Longitude $\left({ }^{\circ} \mathrm{E}\right)$} & \multirow[t]{2}{*}{ Latitude $\left({ }^{\circ} \mathrm{N}\right)$} & \multirow[t]{2}{*}{ Elevation (m) } & \multicolumn{5}{|c|}{ Resistivity $(\Omega \mathrm{m})$} & \multicolumn{4}{|c|}{ Thickness(m) } & \multicolumn{4}{|c|}{ Depth (m) } \\
\hline & & & & $\rho_{1}$ & $\rho_{2}$ & $\rho_{3}$ & $\rho_{4}$ & $\rho_{5}$ & $h_{1}$ & $h_{2}$ & $h_{3}$ & $h_{4}$ & $d_{1}$ & $d_{2}$ & $d_{3}$ & $d_{4}$ \\
\hline VES 1 & 7.4997 & 6.4583 & 189 & 101.2 & 515.4 & 42.3 & 6.2 & 8.9 & 1.4 & 4.1 & 27.8 & 56.4 & 1.4 & 5.6 & 33.4 & 89.8 \\
\hline VES 2 & 7.5008 & 6.4487 & 193 & 161.2 & 346.5 & 98.0 & 88.3 & 3.3 & 1.4 & 2.9 & 5.2 & 40.4 & 1.4 & 4.3 & 9.5 & 49.9 \\
\hline VES 3 & 7.5014 & 6.4585 & 194 & 442.9 & 551.5 & 201.6 & 204.2 & 17.7 & 1.3 & 2.9 & 15.7 & 18.2 & 1.3 & 4.2 & 19.9 & 38.1 \\
\hline VES 4 & 7.4978 & 6.4573 & 193 & 227.0 & 252.9 & 76.5 & 45.0 & 5.1 & 1.9 & 6.3 & 41.3 & 18.2 & 1.9 & 8.2 & 49.6 & 67.8 \\
\hline VES 5 & 7.4998 & 6.5182 & 189 & 101.8 & 499.5 & 41.4 & 9.3 & - & 1.5 & 4.4 & 23.2 & - & 1.5 & 5.9 & 29.1 & - \\
\hline VES 6 & 7.5017 & 6.4583 & 194 & 214.7 & 673.1 & 195.8 & 121.9 & 23.5 & 1.6 & 5.3 & 31.2 & 49.8 & 1.6 & 5.3 & 36.2 & 87.6 \\
\hline VES 7 & 7.4576 & 6.5076 & 191 & 192.5 & 318.1 & 57.2 & 16.9 & - & 1.5 & 6.4 & 40.8 & - & 1.3 & 12.6 & 48.7 & - \\
\hline
\end{tabular}

Table 2 Computed aquifer parameters from measured resistivity and thickness

\begin{tabular}{|c|c|c|c|c|c|c|c|c|c|c|}
\hline VES stations & Longitude $\left({ }^{\circ} \mathrm{E}\right)$ & Latitude $\left({ }^{\circ} \mathrm{N}\right)$ & $\rho_{\mathrm{a}}(\Omega \mathrm{m})$ & $h_{\mathrm{a}}(\mathrm{m})$ & $K$ (m/day) & $\operatorname{Tr}\left(\mathrm{m}^{2} /\right.$ day $)$ & $\phi(\%)$ & $F$ & $\tau$ & Elevation (m) \\
\hline VES 1 & 7.4997 & 6.4583 & 6.2 & 56.4 & 70.45 & 3973.283 & 33.71 & 0.0026 & 0.2935 & 189 \\
\hline VES 2 & 7.5008 & 6.4487 & 88.3 & 40.4 & 5.91 & 238.8735 & 45.66 & 0.0016 & 0.2720 & 193 \\
\hline VES 3 & 7.5014 & 6.4585 & 204.2 & 18.2 & 2.71 & 49.2288 & 49.44 & 0.0014 & 0.2667 & 194 \\
\hline VES 4 & 7.4978 & 6.4573 & 76.5 & 41.3 & 6.76 & 279.1588 & 45.02 & 0.0017 & 0.2730 & 193 \\
\hline VES 5 & 7.4998 & 6.5182 & 41.4 & 23.2 & 11.99 & 278.0601 & 42.26 & 0.0018 & 0.2773 & 189 \\
\hline VES 6 & 7.5017 & 6.4583 & 23.5 & 49.8 & 20.33 & 1012.263 & 39.71 & 0.0020 & 0.2817 & 194 \\
\hline VES 7 & 7.4576 & 6.5076 & 16.9 & 40.8 & 27.65 & 1127.944 & 38.22 & 0.0022 & 0.2844 & 191 \\
\hline
\end{tabular}


Fig. 4 a Geoelectric section across the VES points, b Contour maps showing the variation of aquifer resistivity

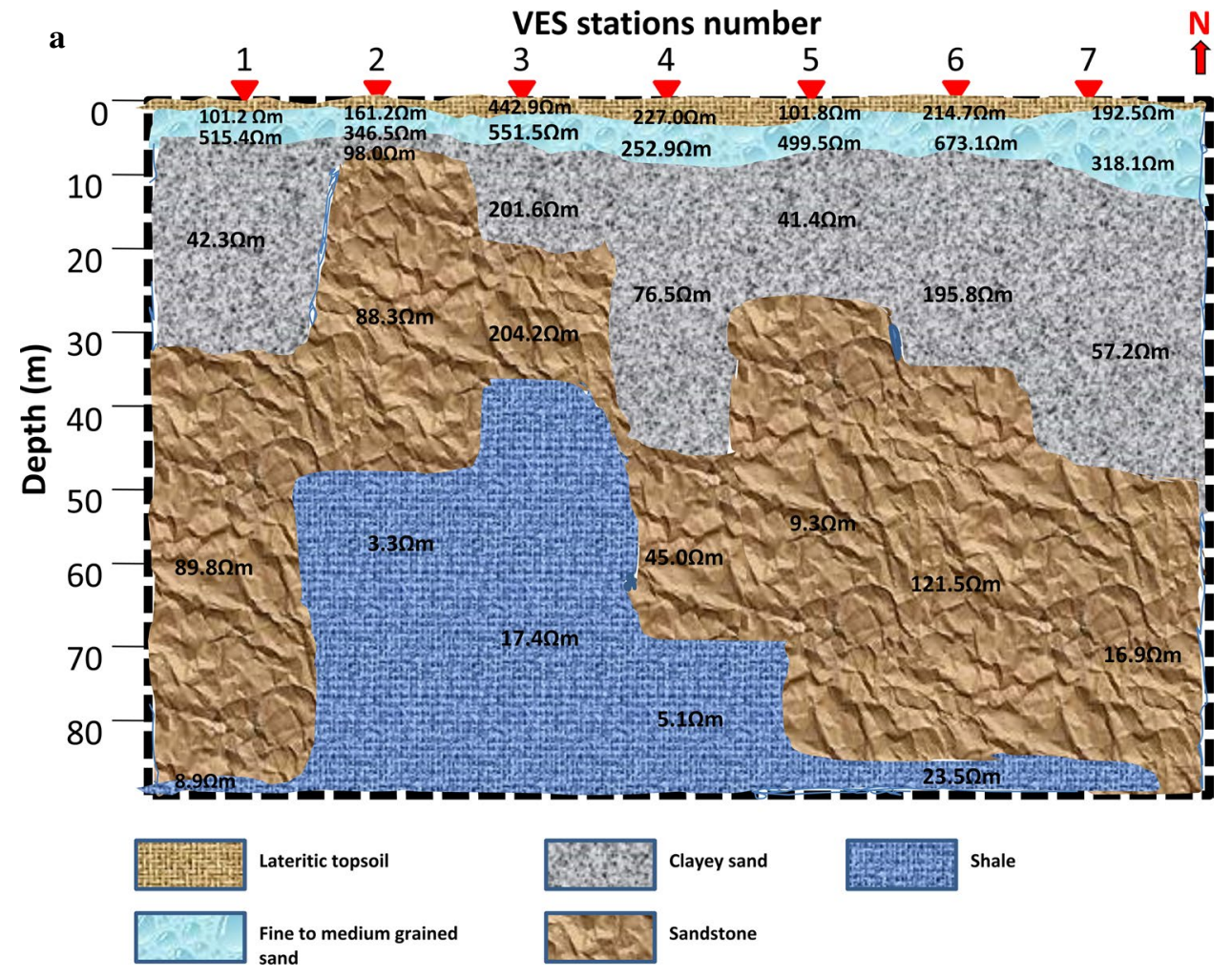

b

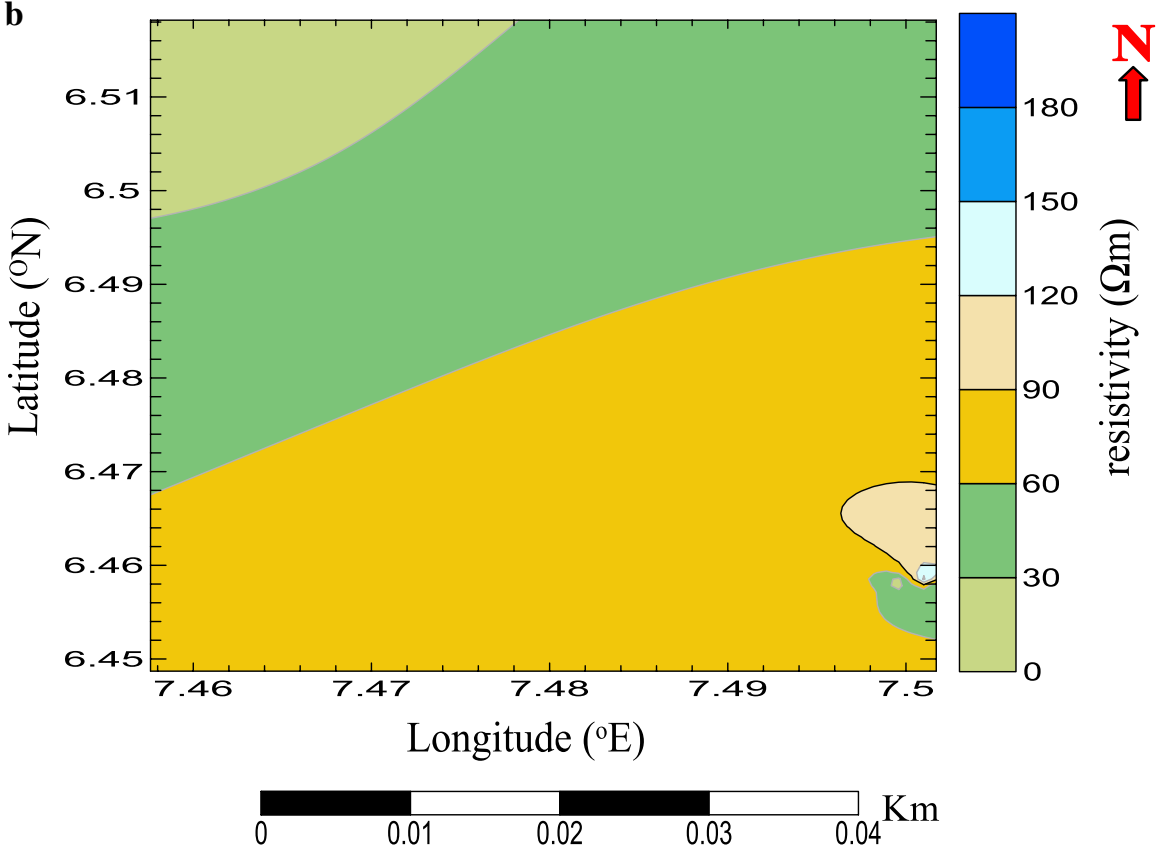

the resistivity of the aquifer layer is shown in Fig. 4b; the resistivity values increases from north towards the southern part of the study area.

The hydraulic conductivity $(\mathrm{k})$ estimated from Eq. (3) ranges from 2.71 to $70.45 \mathrm{~m} /$ day, and the contour map (Fig. 5) shows the variation across the study area. The low values of $K$ observed in some regions may be due to the poor communication channels and geometry of the pore spaces which can affect groundwater flow in the study area (Aleke et al. 2018; George et al. 2018).

The contour map (Fig. 6) shows the variation of aquifer transmissivity with high transmissivity observed at the north-western and south-eastern parts of the study area. The values of this parameter range from 49.2288 to 
Fig. 5 Contour map showing the distribution of hydraulic conductivity

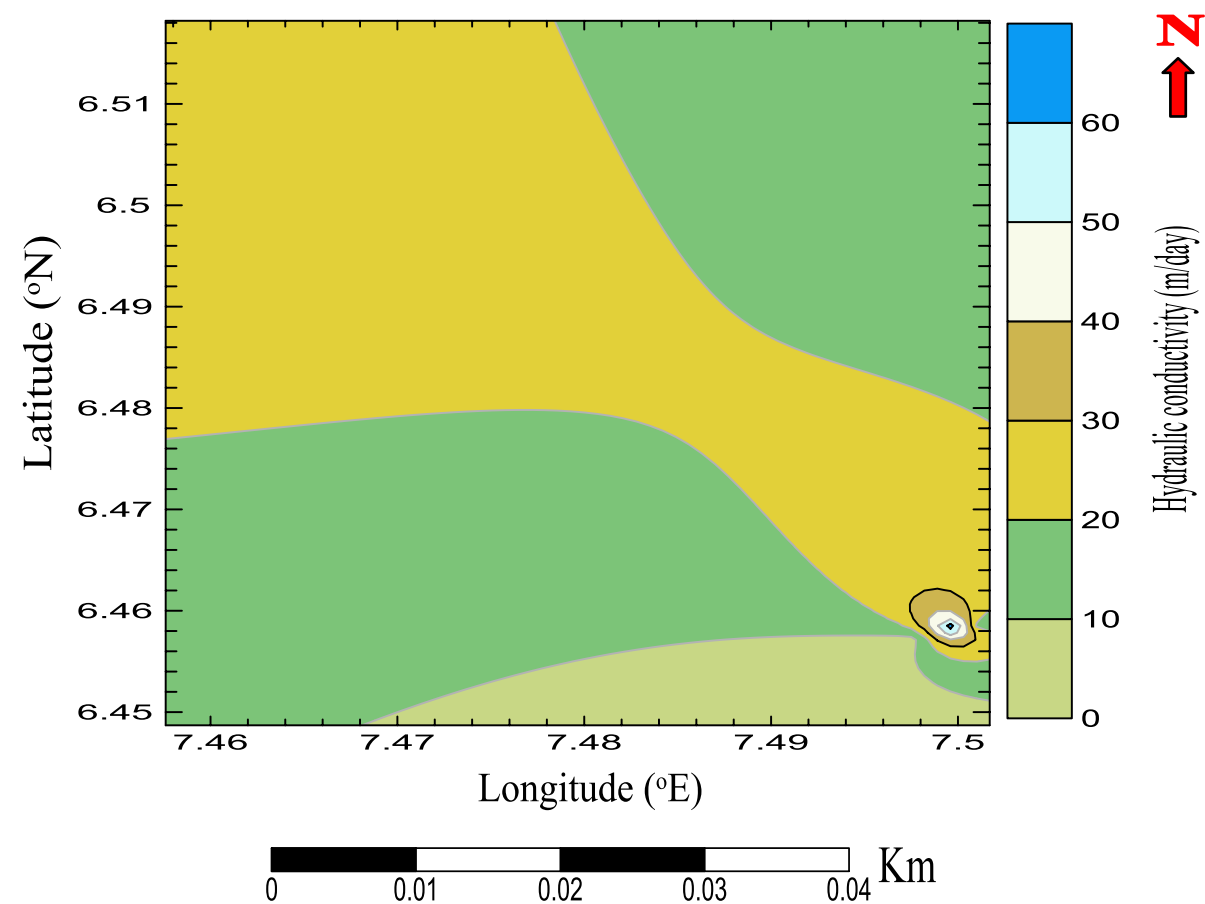

Fig. 6 Contour map showing the distribution of aquifer transmissivity

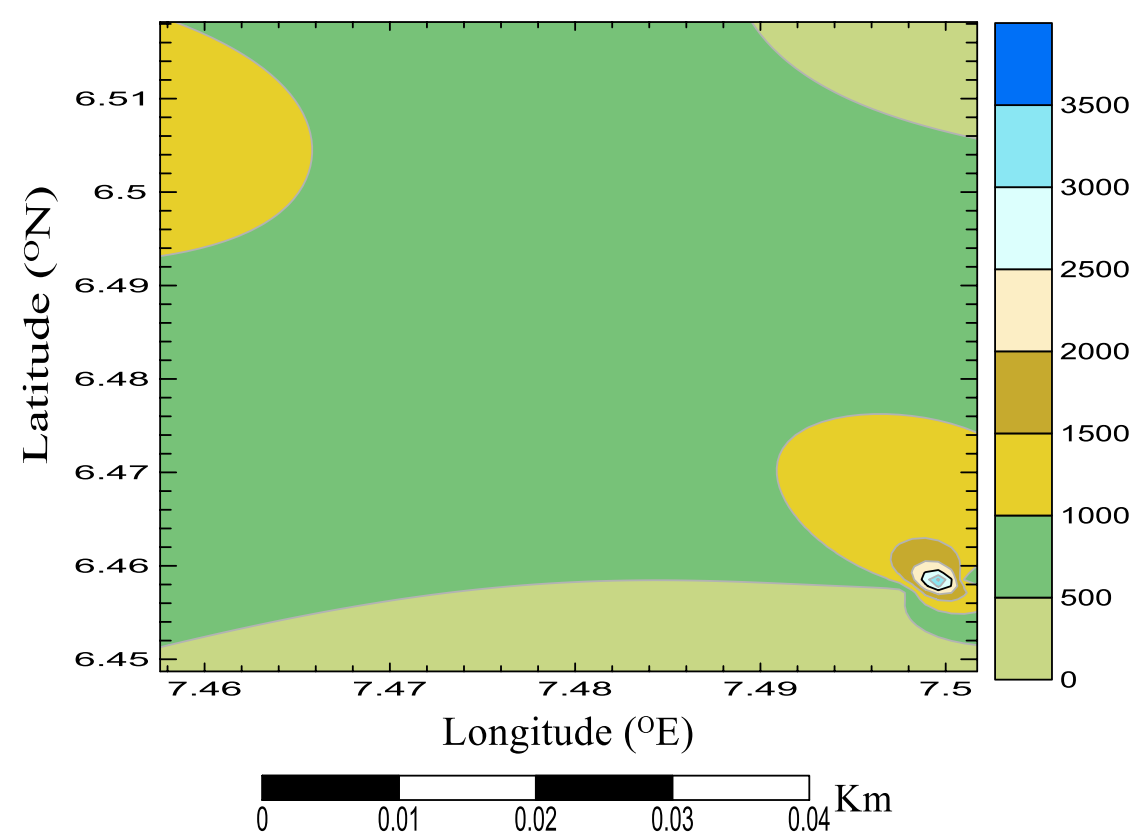

$1127.944 \mathrm{~m} /$ day, which according to Offodile 1983 can be classified as having a moderate to high aquifer transmissivity potentiality. It may be delineated that the aquifer units are fractured which may likely contribute to groundwater occurrence. This corresponds to region with high hydraulic conductivity, hence a productive aquifer. The estimated values of porosity range from 33.71 to $49.44 \%$; this indicates that the study area is dominated by consolidated materials like sand, gravel and clay (Roscoe 1990).
The contour map (Fig. 7) shows the variation of porosity across the study area.

The formation factor estimated according from Archie's law has values ranging from 0.0014 to 0.0026 and is spatially distributed in the study area (Fig. 8). The low values were observed in the southern part of the study area which is a reverse when compared to the trend of porosity. This reflects the heterogeneity of the subsurface and also the subsurface dynamics which control the storage and transmissibility of 
Fig. 7 Contour map showing the distribution of porosity

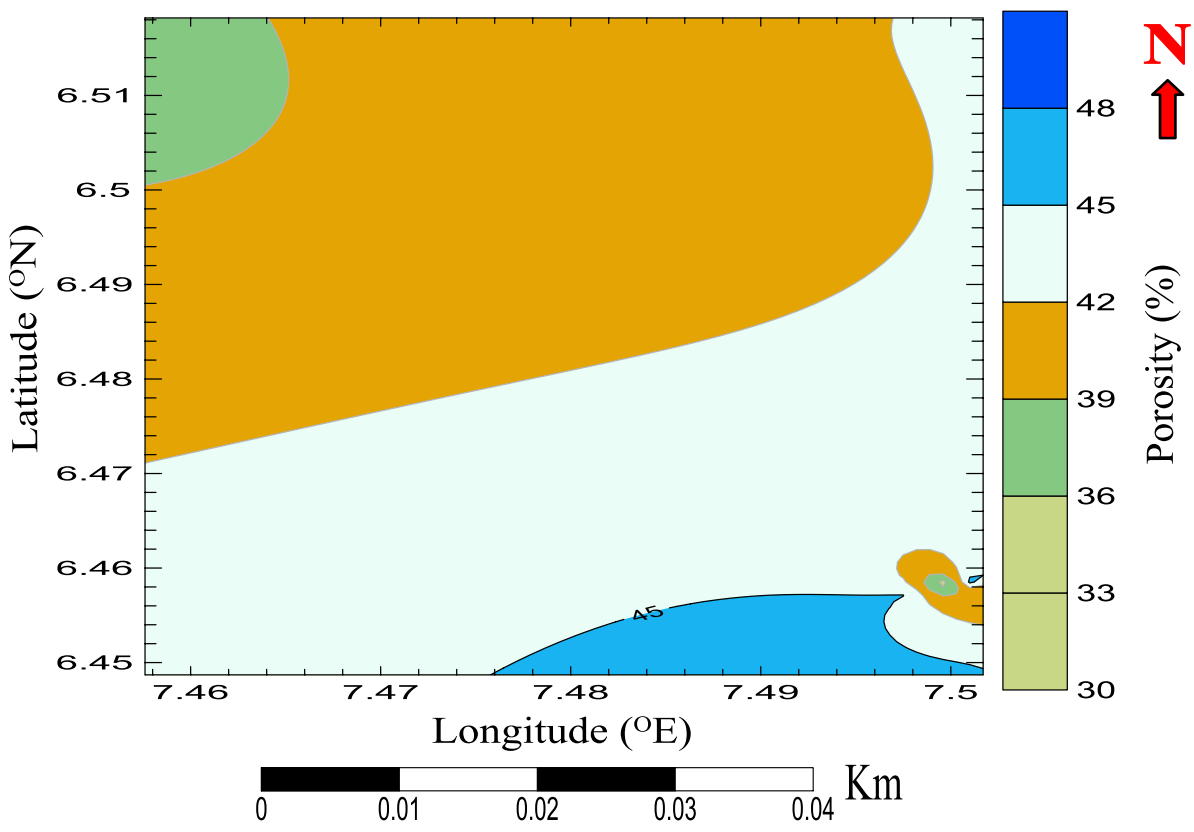

Fig. 8 Contour map showing the distribution of formation factor

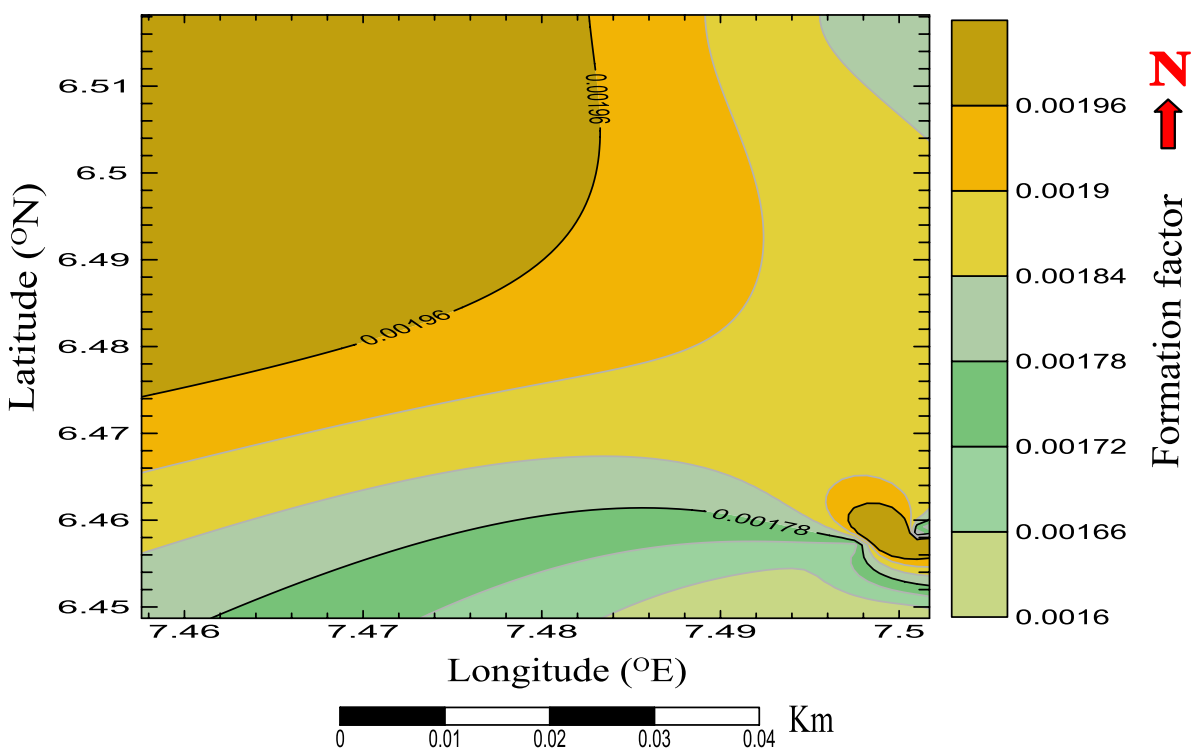

the aquifer units. The parameter (tortuosity) which describes the crook path of groundwater flow is estimated from Eq. (7) and ranged from 0.2667 to 0.2935 . The contour map (Fig. 9) shows the variation of this parameter across the subsurface with low values observed in the southern part of the study area. This trend shows that an increase in formation factor leads to an increase in tortuosity, and their variations are proportional to each other.

The study area elevation ranges from 189 to $194 \mathrm{~m}$ and increases from north to south and corresponds to zone with high resistivity values. This can be used to determine the direction of groundwater flow within the study area (Fig. 10).

\section{Conclusion}

The study revealed the subsurface lithology of the study area characterised by four to five geoelectric layers. The subsurface resistivity, thickness and depth values were obtained from the computer modelling software program. The hydraulic parameters were estimated from the primary aquifer geoelectric parameters and evaluated based on the results. The spatial variations of these parameters are displayed from the contour maps generated from the surfer software package. The aquifer layers shows moderate to high groundwater potential and also the influence of grain 
Fig. 9 Contour map showing the distribution of tortuosity

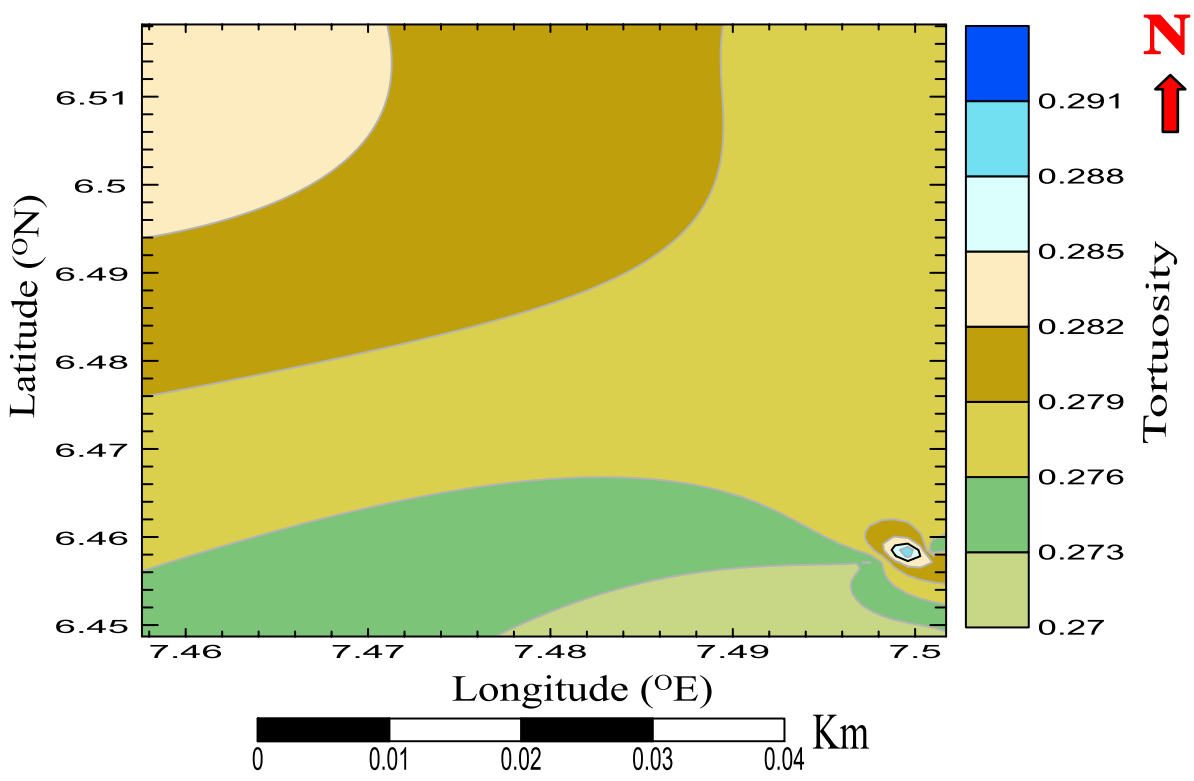

Fig. 10 Contour map showing the distribution of elevation

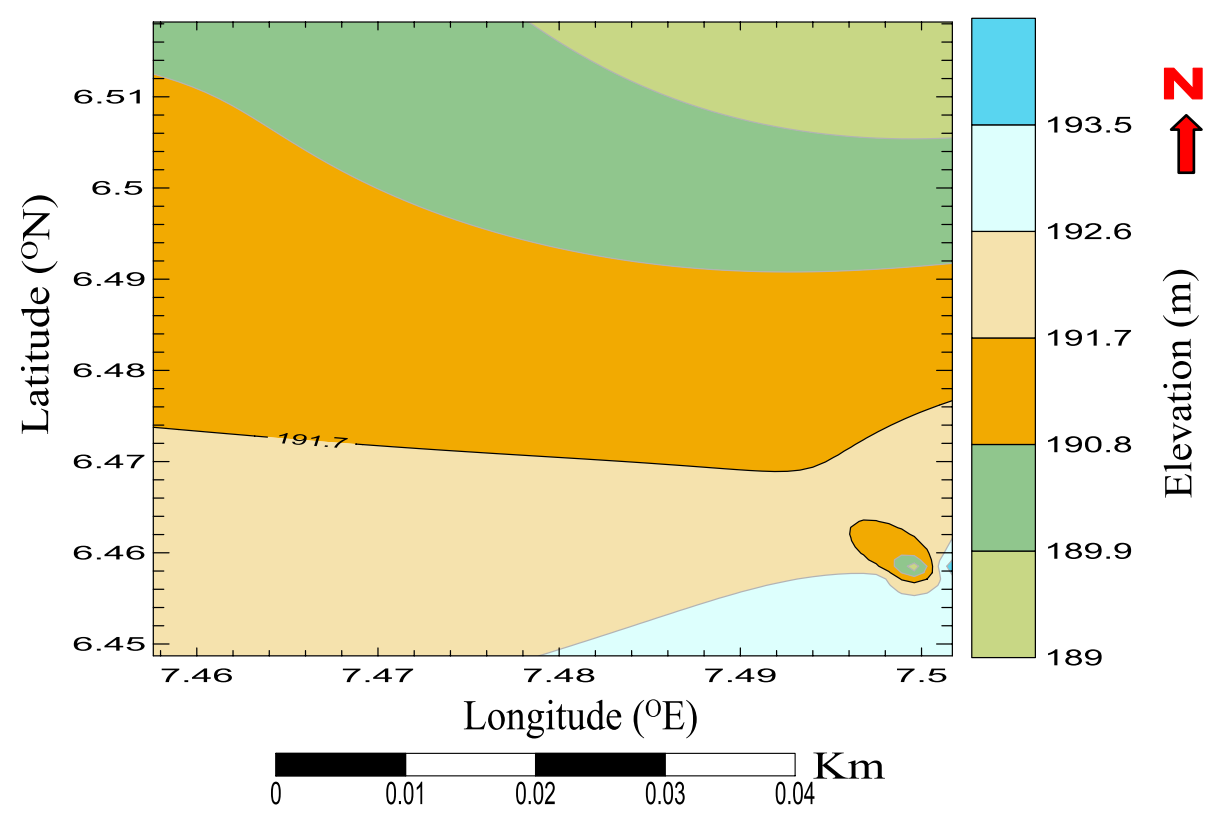

size distribution and the geometry of pore space. Understanding the dynamics and interactions of groundwater flow in a formation is necessary as it contributes to the solution of groundwater abstraction/exploration. It is very important to know how the different hydraulic parameters influence the aquifer behaviour, characteristics and quality of groundwater. This study emphasises the contribution of geophysical methods in the determination and distribution of hydraulic parameters in aquifer repositories.

Acknowledgements The authors are grateful to the Tertiary Education Trust Fund (TETFUND), which financed the project through research grant.
Funding The project was funded by Tertiary Education Trust Fund (TETFUND) which has been acknowledged.

\section{Compliance with ethical standards}

Conflict of interest The authors have declared no conflict of interest.

Human or animal rights This article does not contain studies with human or animal subjects.

Open Access This article is licensed under a Creative Commons Attribution 4.0 International License, which permits use, sharing, adaptation, distribution and reproduction in any medium or format, as long as you give appropriate credit to the original author(s) and the source, 
provide a link to the Creative Commons licence, and indicate if changes were made. The images or other third party material in this article are included in the article's Creative Commons licence, unless indicated otherwise in a credit line to the material. If material is not included in the article's Creative Commons licence and your intended use is not permitted by statutory regulation or exceeds the permitted use, you will need to obtain permission directly from the copyright holder. To view a copy of this licence, visit http://creativecommons.org/licenses/by/4.0/.

\section{References}

Agbasi OE, Etuk SE (2016) Hydro-geoelectric study of aquifer potential in parts of Ikot Abasi Local Government Area, Akwa Ibom State using electrical resistivity soundings. Int J Geol Earth Sci 2(4):43-54

Aleke CG, Ibuot JC, Obiora DN (2018) Application of electrical resistivity method in Estimating geohydraulic properties of a sandy hydrolithofacies: a case study of Ajali Sandstone in Ninth Mile, Enugu State, Nigeria. Arab J Geosci 11:322

Archie GE (1942) The electrical resistivity logs as an aid in determining some reservoir characteristics. Am I Min Met Eng 146:54-62

Dhakate R, Singh VS (2005) Estimation of hydraulic parameters from surface geophysical methods, kaliapani ultramafic Complex, Orissa, India. J Environ Hydrol 13(12):1-11

Egesi N (2017) Structural features of Ajali Sandstone in the Western and Eastern parts of River Niger, Southern Nigeria. J Geog Environ Earth Sci Int 11(2):1-12

George NJ, Nathaniel EU, Etuk SE (2014) Assessment of economical accessible groundwater reserve and its protective capacity in Eastern Obolo Local Government Area of Akwalbom State, Nigeria, using electrical resistivity method. Int J Geophys 7(3):693-700

George JN, Ibuot JC, Obiora DN (2015) Geoelectrohydraulic of shallow sandy in Itu, AkwaIbom State (Nigeria) using geoelectric and hydrogeological measurements. J Afr Earth Sci 110:52-63

George NJ, Ekanem AM, Ibanga JI, Udosen NI (2017) Hydrodynamic implications of aquifer quality index (AQI) and flow zone indicator (FZI) in groundwater abstraction: a case study of coastal hydro-lithofacies in South-eastern Nigeria. J Coast Conserv 21(4):1-18. https://doi.org/10.1007/s11852-017-0535-3

George NJ, Ibuot JC, Ekanem AM, George AM (2018) Estimating the indices of inter-transmissibility magnitude of active surficial hydrogeologic units in Itu, Akwa Ibom State, Southern Nigeria. Arab J Geosci 11(6):1-16

Heigold PC, Gilkeson RH, Cartwright K, Reed PC (1979) Aquifer transmissivity from surficial electrical methods. Groundwater 17(4):338-345

Ibuot JC, Akpabio GT, George NJ (2013) A survey of the repositories of groundwater potential and distribution using geoelectriccal resistivity method in Itu Local Government Area, Akwa Ibom State, Southern Nigeria. Cent Eur J Geosci 5(4):538-547

Ibuot JC, Okeke FN, George NJ, Obiora DN (2017) Geophysical and physicochemical characterization of organic waste contamination of hydrolithofacies in the coastal dumpsite of Akwa Ibom State, Southern Nigeria. Water Sci Tech-W Sup 17(6):1626-1637

Ibuot JC, George NJ, Okwesili AN, Obiora DN (2019) Investigation of litho-textural characteristics of aquifer in Nkanu West Local Government Area of Enugu state, southeastern Nigeria. J Afr Earth Sci 157(2019):197-2017

Kelly WE (1977) Geoelectric sounding for estimating hydraulic conductivity. Groundwater 15:420-425

Marotz G (1968) Technische Grundla geneinerwas serspeicherun gimnaturliche nuntergrund. Verlag Wasser Und Boden, Hamburg

Niwas S, Singhal DC (1981) Estimation of aquifer transmissivity from Dar Zarrouk parameters in porous media. Hydrology 50:393-399

Obiora NO, Adeolu E, Ibuot JC (2015) Evaluation of aquifer protective capacity of overburden unit and soil corrosivity in Makurdi, Benue state, Nigeria, using electrical resistivity method. J Earth Syst Sci 124(1):125-135

Offodile ME (1983) The occurrence and exploitation of groundwater in Nigeria basement complex. J Miner Geol 20:131-146

Orellana E, Mooney H (1966) Master tables and curves for VES over layered structures. Interciencia, Madrid, Spain

Roscoe MC (1990) Handbook of ground water development. Wiley, New-York

Singh RP (1985) Effect of dipping anisotropic substratum on magnetotelluric response. Geophys Prospect 33:369-376

Singh KP (2005) Nonlinear estimation of aquifer parameters from surficial measurements. Hydrol Earth Syst Sci 2:917-938

Soupious P, Papadopoulos I, Kouli M, Georgaki I, Vallianatos F, Kokkinou E (2007) Investigaation of waste disposal areas using electrical methods: a case study from Chania, Crete, Greece. Environ Geol 51(7):1249-1261

Stow DAV (2005) Sedimentary rocks in the field: a colour guide. Mason Publ Ltd, London, p 320

Uzoije AP, Onunkwo AA, Ibeneme SI, Obioha EY (2014) Hydrogeology of Nsukka South-east-a preliminary approach to water resources development. Am J Eng Res 3(1):150-162

Yahaya N, Mat Din M, Noor M, Husna S (2009) Prediction of $\mathrm{CO}_{2}$ corrosion growth in submarine pipelines. Malay J Civ Eng 21(1):69-81

Publisher's Note Springer Nature remains neutral with regard to jurisdictional claims in published maps and institutional affiliations. 